\title{
İşgücüne Katılım Kararı: Nitel Bağımlı Değişkenli Panel Veri Modelleri ${ }^{1}$
}

\begin{abstract}
İşgücüne Katılım Kararı: Nitel Bağımlı Değişkenli Panel Veri Modelleri

Öz

İşgücüne katılım, ekonomik faaliyetlerin arttırılıp büyüme ve kalkınmanın sağlanması açısından önem taşımaktadır. Çalışmanın amacı, çalışma çağında olan bireylerin işgücüne katılım kararları üzerinde sosyo-ekonomik ve demografik etmenler ile 2008 finans krizinin yarattığı etkileri nitel bağımlı değişkenli panel veri modelleriyle incelemektir. Bu amaç doğrultusunda çalışmada, 2008 krizini kapsayan, 2007-2010 Gelir ve Yaşam Koşulları Araştırması Panel Veri Seti kullanılmaktadır. Türkiye'de kadınların işgücüne katılımının düşük olması nedeniyle kadın ve erkekler için ayrı modeller tahmin edilmekte ve karşılaştırma yapılabilmesi sağlanmaktadır. Elde edilen bulgulara göre, kriz döneminde hem kadın hem de erkeklerde işgücüne katılma olasılığı artmaktadır. İşgücüne katılımdaki artış, kadınlarda işsizliğin erkeklerde ise hem istihdam hem de işsizliğin artması ile ortaya çıkmaktadır. Üniversite mezunu olmak, kadınların işgücüne katılımlarında ve istihdamda olmalarında önemli bir belirleyicidir. Evlilik ve hanede küçük çocuk olması kadınların işgücüne katılım olasılığını azaltırken, erkeklerinkini arttırmaktadır.
\end{abstract}

Anahtar Kelimeler: İşgücü Arzı, İşgücüne Katılım, Nitel Bağımlı Değişkenli Panel Veri Modelleri, Panel Logit Model, Panel Multinomial Logit Model
Canan Güneş²
Labor Force Participation Decision: Discrete Dependent Variable Panel Data Models

\begin{abstract}
The labor force participation is important for the growth and development by increasing the economic activities. This study aims to investigate the socioeconomic and demographic factors and the effects of 2008 financial crisis influencing the labor force participation decisions of individuals in working age using discrete dependent variable panel data models. For this purpose, the 2007-2010 Income and Living Conditions Survey Panel Data Set covering the 2008 crisis is used. Since women's labor force participation rate in Turkey is low, separate models are estimated for men and women enabling us to compare the results. According to the findings, the probability of labor force participation is increasing in both women and men during the crisis. The increase in labor force participation is due to the increase in unemployment in women and employment and unemployment in men. Having a university degree is an important determinant of women's labor force participation and employment. While being married and having a child decrease the probability of labor force participation for women, increase the probability of labor force participation for men.
\end{abstract}

Keywords: Labor Supply, Labor Force Participation, Discrete Dependent Variable Panel Data Models, Panel Logit Model, Panel Multinomial Logit Model.

\section{Giriş}

İşgücü arzının temellerini Neoklasik Çalışma/Boş Zaman teorisi oluşturmaktadır. Neoklasik Çalışma/Boş Zaman teorisi işgücü arzı modelini, bireylerin zamanlarını ücret karşılığı çalışarak veya boş zaman olarak tüketeceği varsayımı üzerine kurmuştur. Becker (1965), Zaman Tahsisi Modeli ile Neoklasik Çalışma/Boş Zaman teorisini geliştirmiştir ve işgücü arzı teorisine iki önemli gelişme sağlamıştır. Bunlar birey yerine hanenin karar birimi olarak benimsenmesi ve zamanın işgücü piyasasında çalışma, hane içi üretim ve tüketim olarak tahsis edilmesidir.

İstihdamdaki ve işsiz nüfustan oluşan işgücüne katılım, işgücü arzının bir göstergesidir. İşgücüne katılım; ekonomik faaliyetlerin arttırılıp, büyüme ve kalkınmanın sağlanması açısından önem taşımaktadır. Bireylerin işgücüne katılım kararları, birbirinden farklılık göstermektedir.

\footnotetext{
${ }^{1}$ Bu çalışma Dokuz Eylül Üniversitesi Sosyal Bilimler Enstitüsü Ekonometri Anabilim Dalı’nda Prof.Dr. Şenay Üçdoğruk Birecikli danışmanlığında Canan Güneş tarafından "Panel Veri Kesikli Tercih Modelleri İle Türkiye'de İşgücüne Katılım Kararının Analizi" ismiyle tamamlanarak 17.08.2017 tarihinde savunulan doktora tezinden türetilmiştir.

2 Dr. Öğr. Üyesi, Çanakkale Onsekiz Mart Üniversitesi, Biga IïBF, Ekonometri Bölümü. canangunes@comu.edu.tr, Yazar ORCID Bilgisi: https://orcid.org/0000-0001-9895-7748.
} 
Yatay kesit verisi ile yapılan çalışmalar işgücüne katılım hakkında önemli bilgiler verse de işgücü arzının zaman içinde gösterdiği değişimin ve bu değişim üzerinde etkili olan faktörlerin araştırılması, geliştirilecek politikalar açısından önem taşımaktadır. Bu bağlamda işgücüne katılım çaış̧malarında, zaman serisi ve panel veri çalışmaları zaman içindeki değişim hakkında bilgi verdiği için önemlidir.

Çalışmanın amacı 2007-2010 yıllarında çalışma çağında olan bireylerin işgücüne katılım kararları üzerinde etkili olan sosyo-ekonomik ve demografik etmenleri nitel bağımlı değişkenli panel veri modelleriyle incelemektir. Çalışmada bireylerin bir aile bütçesi kısıtı altında işgücü arzı kararlarını kendi faydalarını en çoklayacak şekilde verdikleri varsayılmaktadır.

2008 'in son çeyreğinde patlak veren Türkiye'de etkileri 2009 'da kendini gösteren finans krizi, gelişmiş ve gelişmekte olan hemen hemen tüm ülkelerin işgücü piyasalarını olumsuz yönde etkilemiştir. Bireylerin işgücüne katılım kararlarında krizin yarattığı etkinin de incelenebilmesi amacıyla, çalışmada Türkiye İstatistik Kurumu (TÜiK) 2007-2010 Gelir ve Yaşam Koşulları Araştırması (GYKA) Panel Veri Seti kullanılmaktadır. Ele alınan zaman aralığı; kriz öncesi, kriz ve sonrası dönemleri kapsadığı için kriz etkilerinin en iyi görülebileceği dönemdir.

2016 Dünya Bankası verilerine göre Türkiye'de kadın işgücüne katılım oranı \%30.4 iken dünya ortalaması \%49.5'tir. Kadınların işgücüne katılımının düşük olması toplumsal cinsiyet eşitsizliğinin derinleşmesine neden olmaktadır (TÜSIAD ve KAGIDER, 2008: 118). Bu noktada çalışmada cinsiyet farklııklarının incelenmesi amacıyla, kadın ve erkekler için model tahminleri yapılmakta; sonuçlar karşılaştırılmalı olarak sunulmakta ve yorumlanmaktadır.

Türkiye'de bireysel işgücü arzını dengeli panel ile iki durumlu ve çok durumlu panel tercih modellerini kullanarak inceleyen öncü çalışma olması önem arz etmektedir. Ayrıca kadın ve erkekler için farklı modellerin kullanılması elde edilen tahmin sonuçlarının karşılaştırılması konusunda avantaj sağlamaktadır.

Çalışma altı bölümden oluşmaktadır. İkinci bölümde nitel bağımlı değişkenli panel veri modelleri ile işgücüne katılım kararını inceleyen literatüre yer verilmektedir. Üçüncü bölümde ise veriler ve tanımlayıcı istatistikler sunulmaktadır. Dördüncü bölümde metodoloji ve kullanılan ekonometrik yöntemlere ilişkin teori; sonraki bölümde de ekonometrik model tahminleri ve yorumları anlatılmaktadır. Son bölümde ise çalışmanın sonuçları ve politika önerileri bulunmaktadır.

\section{Literatür}

İşgücü piyasasına ilişkin durağan, tek döneme ait istatistikler işgücü piyasasının dinamik yapısına yönelik bilgi sağlamamaktadır. Panel veri kullanımının önemini vurgulayan öncü çalışma Heckman ve Willis (1977) tarafından gerçekleştirilmiştir. Çalışmada geleneksel logit modeli, heterojen bir anakütleden elde edilen panel verilerde iki durumlu tercih (var-yok gibi) sorununun üstesinden gelmek amacıyla kullanılmış ve evli kadınların işgücüne katılımında heterojenliğin önemli olduğu vurgulanmıştır. Nakamura ve Nakamura (1985) ise çalışmalarında evli kadınların işgücüne katılma davranışlarını yatay-kesit modelleri ile incelemenin zaman boyunca gözlemlenen sürekliliği ortaya koymada yetersiz olacağını belirtmiştir.

Bireylerin işgücü piyasası durumlarının, zaman içindeki değişimini inceleyen çalışmalar genel olarak üç sınıfta toplanmaktadır. Illk grupta yer alan çalışmalarda bireyin işgücü durumunun zaman içindeki değişimi panel veri tercih modelleri ile incelenmekte ve genellikle dinamik modeller kullanılmaktadır. İkinci gruptaki çalışmalarda işgücü durumları arasındaki geçiş matrisleri 
elde edilmekte ve geçiş olasılıkları; bireysel özellikler ve işgücü piyasası koşullarının bir fonksiyonu olarak, çoğunlukla Multinomial Logit (MNL) modeli ile tahmin edilmektedir. Üçüncü gruptaki çalışmalar ise bireyin işsiz kalma süresini etkileyen bireysel özellikleri ve piyasa koşullarını süre modelleri ile analiz etmektedir. Çalışmada bireylerin işgücü durumları arasında zamanlararası değişim nitel bağımlı değişkenli panel veri modelleri kullanılarak incelenmektedir ve literatür taramasında sadece bu modellerden yararlanan çalışmalara yer verilmektedir.

Zamanlar arası işgücüne katılım kararının dinamiklerini nitel bağımlı değişkenli panel veri modelleri ile inceleyen birçok çalışma bulunmaktadır. Öncü çalışmalardan birinde Hyslop (1999); evli kadınların işgücüne katılım kararı ile doğurganlık, emek dışı elde edilen gelir ve şu andaki işgücü durumu arasındaki ilişkiyi analiz etmiştir. Elde edilen bulgular işgücüne katılım kararının; anlamlı durum bağımlılığı (state dependence), gözlenemeyen heterojenlik ve hata bileşeninde negatif serisel korelasyon tarafından belirlendiğini göstermiştir. Keane ve Sauer (2010) ise Hyslop (1999)'un çalışmasını, kayıp gözlem ve başlangıç durumu sorunlarını göz önünde bulundurarak geliştirmiştir. Evli kadınların işgücü arzı modelinde açıklayıcı değişken olarak eşin ortalama yıllık geliri, 0-2, 3-5 ve 6-17 yaş arası çocuk sayısı, yaş, eğitim düzeyi ve ırk değişkenleri kullanılmıştır.

Haan (2010) kadın işgücüne katılım ve çalışma saatini dikkate alarak işgücü arzı davranışında gerçek durum bağımlılığının etkisini incelemiştir. Durum bağımlılı̆̆ı; işgücüne katılım üzerinde pozitif ve anlamlı etki gösterirken, çalışma saati üzerinde anlamlı ve düşük etkiye sahiptir. Croda ve diğerleri (2011) evli kadınların zamanlar arası işgücüne katılım kararlarını incelemiştir. Modellerde güçlü durum bağımlılığı olduğu görülmüştür. Ayrıca doğurganlığın işgücüne katılım kararında önemli bir etken olduğu ortaya koyulmuştur. Geçici ve sürekli emek dışı gelirin etkisinin küçük olduğu vurgulanmıştır. Shiu ve Hu (2013) tarafından gerçekleştirilen çalışmada evli kadınların işgücüne katılım kararında önceki işgücü durumu, doğurganlık kararı ve emek dışı gelirin etkisi dinamik panel veri modelleri kullanılarak incelenmiştir. Elde dilen bulgular emek dışı gelirin ve $0-2$ yaşında çocuk sahibi olmanın işgücüne katılımı negatif etkilediğini göstermiştir. Ayrıca önceki dönemdeki işgücü durumu ile şimdiki işgücü durumu arasında anlamlı ve güçlü ilişki olduğu bulunmuştur.

Cai (2010) evli kadınların işgücü piyasasında yüksek seviyede süreklilik göstermesini etkileyen etmenleri incelemiştir. Ayrıca eğitim, gelir, yaş, sağlık durumu ve çocuk sahipliğinin evli kadınların işgücü arzı kararları üzerindeki etkisini de araştırmıştır. Elde edilen bulgulara göre evli kadınların işgücü arzı, geçmiş işgücü arzı kararlarından etkilenmemektedir. Emek dışı elde edilen gelir, eğitim, sağlık, çocuk sayısı ve yaş evli kadınların işgücü arzı üzerinde anlamlı etkiye sahiptir.

Cinsiyet ayrımını göz önünde bulundurarak yapılan çalışmalardan biri Booth ve diğerleri (1999) tarafından yapılmıştır. Çalışmada kadın ve erkekler için ücretli çalışmaya katılma kararı incelenmiştir. Zaman boyunca erkeklerin ücretli işlerde çalışma ihtimalinin, kadınların ise işsiz olma olasılığının daha yüksek olduğu sonucuna ulaşılmıştır. Çalışmada ücretli çalışan olma eğiliminin cinsiyete göre farklılığında etkili olan etmenler incelenmiş ve ücretli çalışan olma eğiliminin kadın ve erkekler için farklı olmasının gözlemlenen ve gözlemlenemeyen bireysel özelliklerden kaynaklandığı gösterilmiştir.

Literatürde iki durumlu panel tercih modellerinin dışında çok durumlu panel tercih modellerinin kullanıldığı çalışmalar da bulunmaktadır. Haynes ve diğerleri (2006) tam zamanlı çalışan, yarı zamanlı çalışan ve çalışmayan olmak üzere evli kadınların üç istihdam durumu arasındaki 
tercihlerini tesadüfi etkiler MNL modeli ile incelemiştir ve en iyi tahminleme yöntemini araştırmıştır. Uyarlamalı Gausçu kareselleştirmesi ve Markov Zinciri Monte Carlo (MCMC) yöntemlerinin karşılaştırıldığı çalışmada üç model kullanıımıştır. Bunlardan ilkinde tesadüfi etkilerin göz ardı edildiği durağan havuzlanmış MNL modeli ile sonuçlar elde edilmiştir. İkincisinde bireyler arasındaki gözlemlenemeyen heterojenliğin üstesinden gelmek amacıyla korelasyonlu tesadüfi kesmelerin olduğu MNL modeli tahmin edilmiştir. Son modelde ise durum bağımlılığını dikkate almak amacıyla geciktirilmiş bağımlı değişken ile dinamik tesadüfi etkiler MNL modeli kullanılmıştır. Çalışmada açıklayıcı değişken olarak bireyin yaşı, medeni durumu, sahip olunan çocuk sayısı, en küçük çocuğun yaşı, eğitim düzeyi ve eşin geliri kullanılmıştır.

Kadınların tam zamanlı istihdam, yarı zamanlı istihdam ve işgücü dışı durumları arasındaki tercihini inceleyen bir diğer çalışma Prowse (2012) tarafından gerçekleştirilmiştir. Dinamik karma MNL modelinin kullanıldığı analizde önceki dönemde istihdamda olmanın, çocuk sahipliği ve eğitimin işgücü arzı üzerindeki etkisi gözlemlenen heterojenliğe izin verilerek araştırılmıştır. Elde edilen bulgulara göre çocuk sahibi olmak ve eğitim, işgücü arzı üzerinde anlamlı farklılıklar yaratmaktadır.

Hyder ve Behrman (2014) çalışmalarında tarımla ilgili işler, satışla ilgili işler, ev içi üretim sanayi, diğer ekonomik faaliyetlerde çalışanlar ve çalışmayanlar olmak üzere beş işgücü piyasası durumu arasındaki kadınların tercihi üzerinde yaş, etnik köken ve medeni durumun etkili olduğu sonucuna ulaşmıştır. Lechmann ve Wunder (2016) Almanya'da dört işgücü durumu (tek başına kendi hesabına çalışan, işveren, ücretli istihdam, işsiz) için kadın ve erkeklerin dinamik MNL modeli sonuçlarını sunmuştur.

Türkiye'de işgücü piyasası üzerine yapılan çalışmalar incelendiğinde, çalışmaların çoğunda yatay kesit ya da zaman serisi verilerinin kullanıldığı görülmektedir. Panel veri kullanılarak yapılan çalışmalar ise genelde makro boyutlu olup, ülkelere ilişkin verileri panel veri analizi ile incelemektedir. Özer ve Biçerli (2003) kadınların işgücüne katılım oranlarını inceledikleri çalışmalarında; Türkiye'de kadın işgücünün makro nitelikteki değişkenlerden doğrudan etkilenmediğini, birime özgü özellikleri veren mikro değişkenlerden etkilendiğini ortaya koymuştur.

Türkiye'de işgücü piyasası durumları arasındaki geçişleri Markov geçiş modelleri ile inceleyen farklı çalışmalar bulunmaktadır (Taşçı ve Tansel (2005a), Taşçı ve Tansel (2005b), íkizler ve Tunalı (2012), Tansel ve Kan (2012), Bahçe ve Memiş (2014), Alcan ve diğerleri (2015), Acar ve Tansel (2016) vb.). Ancak Türkiye'de işgücü piyasası durumlarını panel veri kesikli tercih modelleri ile inceleyen sadece bir çalışmaya rastlanmıştır. 2007-2010 dönemi GYKA panel veri setini kullanan Selim ve diğerleri (2014) analiz aşamasında istihdamda ve işsizleri gösteren iki durumlu bağımlı değişkeni kullanmıştır. Her yıl için logit model sonuçları ve dört yıllık dönem için dengesiz panel ile panel logit model tahmini sunulmuştur. Açıklayıcı değişken olarak cinsiyet, medeni durum, eğitim, yaş, bireyin sağlık durumu, işteki durumu ve mesleği kullanılmıştır. Elde edilen bulgulara göre erkekler ve evlilerin işsiz olma olasılığı daha yüksektir. Ayrıca eğitim seviyesi arttıkça kişinin işsiz olma olasılığı da artmaktadır. Deneyim bireyin işsiz olma olasılığını azaltırken, genç nüfusunkini arttırmaktadır.

\section{Veri ve Tanımlayıcı İstatistikler}

Çalışmanın amacı doğrultusunda 2008 finans krizinin öncesi, kriz süreci ve sonrası dönemi en iyi yansıtacağı düşünülen TÜik tarafından hazırlanan 2007-2010 GYKA Panel Veri Seti kullanılmaktadır. Alt örneklem uygulaması nedeniyle söz konusu veri setinde; 2007, 2008, 2009 ve 
2010 yıllarında anket uygulanan hane ve fertlere ilişkin dört, üç ve iki yıllık veriler bir arada bulunmaktadır. Çalışmanın kapsamı gereği dört yıl boyunca izlenen ilk alt örneklem ile çalışımaktadır. Diğer alt örnekler ise veri setinden çıkarılmıştır.

Çalışma çağındaki nüfus belirlenirken yaş kriteri dikkate alınmaktadır. Literatürdeki çalışmalar incelendiğinde çalışma çağının 15-64 yaş arası olarak kabul edildiği görülmüştür. Bu nedenle çalışmada 15-64 yaş arası bireyler ile çalışılmaktadır. Çalışma 2007-2010 dönemini kapsamaktadır. Bu doğrultuda 2007 yılında 15 ve üzeri yaşta olan, 2010 yılında ise 64 ve altı yaşta olan bireyler örneklemde yer almaktadır.

Tablo 1: Tanımlayıcı Istatistikler

\begin{tabular}{|c|c|c|c|c|c|c|c|c|}
\hline \multirow[b]{2}{*}{ Değişkenler } & \multicolumn{4}{|c|}{ KADIN } & \multicolumn{4}{|c|}{ ERKEK } \\
\hline & $\begin{array}{c}2007 \\
\text { Ortalama } \\
\text { (Standart } \\
\text { sapma) } \\
\end{array}$ & $\begin{array}{c}2008 \\
\text { Ortalama } \\
\text { (Standart } \\
\text { sapma) } \\
\end{array}$ & $\begin{array}{c}2009 \\
\text { Ortalama } \\
\text { (Standart } \\
\text { sapma) } \\
\end{array}$ & $\begin{array}{c}2010 \\
\text { Ortalama } \\
\text { (Standart } \\
\text { sapma) } \\
\end{array}$ & $\begin{array}{c}2007 \\
\text { Ortalama } \\
\text { (Standart } \\
\text { sapma) } \\
\end{array}$ & $\begin{array}{c}2008 \\
\text { Ortalama } \\
\text { (Standart } \\
\text { sapma) } \\
\end{array}$ & $\begin{array}{c}2009 \\
\text { Ortalama } \\
\text { (Standart } \\
\text { sapma) } \\
\end{array}$ & $\begin{array}{r}2010 \\
\text { Ortalama } \\
\text { (Standart } \\
\text { sapma) } \\
\end{array}$ \\
\hline \multicolumn{9}{|c|}{ İ̧̧øücü Durumu } \\
\hline İşgücüne & 0.6822 & 0.6542 & 0.6408 & 0.6442 & 0.1992 & 0.1880 & 0.1768 & 0.2018 \\
\hline $\begin{array}{l}\text { dahil olma- } \\
\text { yan }\end{array}$ & $(0.4657)$ & $(0.4757)$ & $(0.4798)$ & $(0.4788)$ & $(0.3995)$ & $(0.3908)$ & $(0.3816)$ & $(0.4014)$ \\
\hline İşgücüne & 0.3178 & 0.3458 & 0.3592 & 0.3558 & 0.8008 & 0.8120 & 0.8232 & 0.7982 \\
\hline dahil & $(0.4657)$ & $(0.4757)$ & (0.4798) & $(0.4788)$ & (0.3995) & $(0.3908)$ & $(0.3816)$ & $(0.4014)$ \\
\hline & 0.3040 & 0.3268 & 0.3338 & 0.3301 & 0.7512 & 0.7628 & 0.7516 & 0.7434 \\
\hline Istihdam & $(0.4601)$ & $(0.4691)$ & $(0.4717)$ & $(0.4703)$ & $(0.4324)$ & $(0.4254)$ & $(0.4322)$ & $(0.4368)$ \\
\hline İşsiz & $\begin{array}{c}0.0138 \\
(0.1166) \\
\end{array}$ & $\begin{array}{c}0.0190 \\
(0.1366) \\
\end{array}$ & $\begin{array}{c}0.0254 \\
(0.1572) \\
\end{array}$ & $\begin{array}{c}0.0257 \\
(0.1583) \\
\end{array}$ & $\begin{array}{c}0.0496 \\
(0.2171) \\
\end{array}$ & $\begin{array}{c}0.0492 \\
(0.2162) \\
\end{array}$ & $\begin{array}{c}0.0716 \\
(0.2579) \\
\end{array}$ & $\begin{array}{c}0.0548 \\
(0.2276) \\
\end{array}$ \\
\hline \multicolumn{9}{|c|}{ Medeni Durum } \\
\hline Bekar & $\begin{array}{c}0.2355 \\
(0.4244)\end{array}$ & $\begin{array}{c}0.2422 \\
(0.4285)\end{array}$ & $\begin{array}{c}0.2466 \\
(0.4311)\end{array}$ & $\begin{array}{c}0.2507 \\
(0.4335)\end{array}$ & $\begin{array}{c}0.2117 \\
(0.4086)\end{array}$ & $\begin{array}{c}0.2044 \\
(0.4033)\end{array}$ & $\begin{array}{c}0.1988 \\
(0.3992)\end{array}$ & $\begin{array}{c}0.1932 \\
(0.3949)\end{array}$ \\
\hline Evli & $\begin{array}{c}0.7645 \\
(0.4244) \\
\end{array}$ & $\begin{array}{c}0.7578 \\
(0.4285) \\
\end{array}$ & $\begin{array}{c}0.7534 \\
(0.4311) \\
\end{array}$ & $\begin{array}{c}0.7493 \\
(0.4335) \\
\end{array}$ & $\begin{array}{c}0.7883 \\
(0.4086) \\
\end{array}$ & $\begin{array}{c}0.7956 \\
(0.4033) \\
\end{array}$ & $\begin{array}{c}0.8012 \\
(0.3992) \\
\end{array}$ & $\begin{array}{c}0.8068 \\
(0.3949) \\
\end{array}$ \\
\hline \multicolumn{9}{|c|}{ Eğitim Durumu } \\
\hline $\begin{array}{l}\text { Bir okul bi- } \\
\text { tirmemiş }\end{array}$ & $\begin{array}{c}0.2712 \\
(0.4447)\end{array}$ & $\begin{array}{c}0.2705 \\
(0.4443)\end{array}$ & $\begin{array}{c}0.2716 \\
(0.4449)\end{array}$ & $\begin{array}{c}0.2716 \\
(0.4449)\end{array}$ & $\begin{array}{c}0.0793 \\
(0.2703)\end{array}$ & $\begin{array}{c}0.0737 \\
(0.2614)\end{array}$ & $\begin{array}{c}0.0724 \\
(0.2593)\end{array}$ & $\begin{array}{c}0.0703 \\
(0.2557)\end{array}$ \\
\hline $\begin{array}{l}\text { İlkokul me- } \\
\text { zunu }\end{array}$ & $\begin{array}{c}0.4266 \\
(0.4947)\end{array}$ & $\begin{array}{c}0.4277 \\
(0.4948)\end{array}$ & $\begin{array}{c}0.4262 \\
(0.4946)\end{array}$ & $\begin{array}{c}0.4266 \\
(0.4947)\end{array}$ & $\begin{array}{c}0.4515 \\
(0.4977)\end{array}$ & $\begin{array}{c}0.4532 \\
(0.4979)\end{array}$ & $\begin{array}{c}0.4541 \\
(0.4980)\end{array}$ & $\begin{array}{c}0.4545 \\
(0.4980)\end{array}$ \\
\hline $\begin{array}{l}\text { Ortaokul } \\
\text { mezunu }\end{array}$ & $\begin{array}{c}0.1107 \\
(0.3138)\end{array}$ & $\begin{array}{c}0.1032 \\
(0.3043)\end{array}$ & $\begin{array}{c}0.0980 \\
(0.2974)\end{array}$ & $\begin{array}{c}0.0905 \\
(0.2870)\end{array}$ & $\begin{array}{c}0.1652 \\
(0.3714)\end{array}$ & $\begin{array}{c}0.1600 \\
(0.3667)\end{array}$ & $\begin{array}{c}0.1539 \\
(0.3610)\end{array}$ & $\begin{array}{c}0.1462 \\
(0.3534)\end{array}$ \\
\hline $\begin{array}{l}\text { Lise me- } \\
\text { zunu }\end{array}$ & $\begin{array}{c}0.1349 \\
(0.3417)\end{array}$ & $\begin{array}{c}0.1379 \\
(0.3448)\end{array}$ & $\begin{array}{c}0.1401 \\
(0.3471)\end{array}$ & $\begin{array}{c}0.1457 \\
(0.3528)\end{array}$ & $\begin{array}{c}0.2070 \\
(0.4052)\end{array}$ & $\begin{array}{c}0.2143 \\
(0.4104)\end{array}$ & $\begin{array}{c}0.2160 \\
(0.4116)\end{array}$ & $\begin{array}{c}0.2204 \\
(0.4146)\end{array}$ \\
\hline $\begin{array}{l}\text { Üniversite } \\
\text { ve üzeri } \\
\text { mezunu }\end{array}$ & $\begin{array}{c}0.0566 \\
(0.2312)\end{array}$ & $\begin{array}{c}0.0607 \\
(0.2389)\end{array}$ & $\begin{array}{c}0.0641 \\
(0.2449)\end{array}$ & $\begin{array}{c}0.0656 \\
(0.2476)\end{array}$ & $\begin{array}{c}0.0970 \\
(0.2961)\end{array}$ & $\begin{array}{c}0.0987 \\
(0.2984)\end{array}$ & $\begin{array}{c}0.1035 \\
(0.3047)\end{array}$ & $\begin{array}{c}0.1087 \\
(0.3113)\end{array}$ \\
\hline İş Tecrübesi & $\begin{array}{c}6.9795 \\
(10.8240)\end{array}$ & $\begin{array}{c}7.9642 \\
(11.3912)\end{array}$ & $\begin{array}{c}8.5876 \\
(11.6418)\end{array}$ & $\begin{array}{c}8.7798 \\
(11.7182)\end{array}$ & $\begin{array}{c}17.2803 \\
(11.4727)\end{array}$ & $\begin{array}{c}18.1540 \\
(11.5923)\end{array}$ & $\begin{array}{c}19.2669 \\
(11.7429)\end{array}$ & $\begin{array}{c}19.3381 \\
(12.0862)\end{array}$ \\
\hline Bireyin Yaşı & $\begin{array}{c}36.5160 \\
(12.4996)\end{array}$ & $\begin{array}{c}37.5160 \\
(12.4996)\end{array}$ & $\begin{array}{c}38.5160 \\
(12.4996)\end{array}$ & $\begin{array}{c}39.5160 \\
(12.4996)\end{array}$ & $\begin{array}{c}37.7840 \\
(12.2035)\end{array}$ & $\begin{array}{c}38.7840 \\
(12.2035)\end{array}$ & $\begin{array}{c}39.7840 \\
(12.2035)\end{array}$ & $\begin{array}{c}40.7840 \\
(12.2035)\end{array}$ \\
\hline $\begin{array}{l}\text { Bireyin Ya- } \\
\text { şının Karesi } \\
\text { (Hanenin }\end{array}$ & $\begin{array}{c}1489.6020 \\
(940.47)\end{array}$ & $\begin{array}{c}1563.6340 \\
(965.13)\end{array}$ & $\begin{array}{c}1639.6660 \\
(989.81)\end{array}$ & $\begin{array}{c}1717.6980 \\
(1014.51)\end{array}$ & $\begin{array}{c}1576.4890 \\
(925.43)\end{array}$ & $\begin{array}{c}1653.0560 \\
(949.50)\end{array}$ & $\begin{array}{c}1731.6240 \\
(973.58)\end{array}$ & $\begin{array}{c}1812.192 \\
(997.68)\end{array}$ \\
\hline $\begin{array}{l}\text { Geliri - Bire- } \\
\text { yin Ge- } \\
\text { liri)/1000 }\end{array}$ & $\begin{array}{c}11.6259 \\
(11.4967)\end{array}$ & $\begin{array}{c}11.4489 \\
(10.2270)\end{array}$ & $\begin{array}{c}11.7233 \\
(10.8711)\end{array}$ & $\begin{array}{l}11.3971 \\
(9.2685)\end{array}$ & $\begin{array}{c}6.4384 \\
(8.4241)\end{array}$ & $\begin{array}{c}6.3671 \\
(7.7863)\end{array}$ & $\begin{array}{c}6.6040 \\
(8.4442)\end{array}$ & $\begin{array}{c}6.3528 \\
(7.0093)\end{array}$ \\
\hline \multicolumn{9}{|c|}{ Hanede 5 ve daha Küçük Yaşta Çocuk Olması } \\
\hline Yok & $\begin{array}{c}0.6550 \\
(0.4755)\end{array}$ & $\begin{array}{c}0.6580 \\
(0.4745)\end{array}$ & $\begin{array}{c}0.6777 \\
(0.4674)\end{array}$ & $\begin{array}{c}0.6867 \\
(0.4639)\end{array}$ & $\begin{array}{c}0.6460 \\
(0.4783)\end{array}$ & $\begin{array}{c}0.6490 \\
(0.4774)\end{array}$ & $\begin{array}{c}0.6606 \\
(0.4736)\end{array}$ & $\begin{array}{c}0.6688 \\
(0.4707)\end{array}$ \\
\hline Var & $\begin{array}{c}0.3450 \\
(0.4755)\end{array}$ & $\begin{array}{c}0.3420 \\
(0.4745)\end{array}$ & $\begin{array}{c}0.3223 \\
(0.4674)\end{array}$ & $\begin{array}{c}0.3133 \\
(0.4639)\end{array}$ & $\begin{array}{c}0.3540 \\
(0.4783)\end{array}$ & $\begin{array}{c}0.3510 \\
(0.4774)\end{array}$ & $\begin{array}{c}0.3394 \\
(0.4736)\end{array}$ & $\begin{array}{c}0.3312 \\
(0.4707)\end{array}$ \\
\hline
\end{tabular}

Tablo 1'de ekonometrik modellerde kullanılan değişkenlere ilişkin ortalama ve standart sapmalar 2007, 2008, 2009 ve 2010 yılları için cinsiyet ayrımı gözeterek sunulmaktadır. Veri setinde yer alan 5,003 bireyin 2,684'ü (\%53.65) kadınlardan ve 2,319'u da erkeklerden oluşmaktadır. 
Kadın ve erkeklerin işgücüne katılım kararlarında medeni durum, eğitim düzeyi, iş tecrübesi, yaş, hanede beş yaşından küçük çocuk olması ve hanenin geliri ile ferdin geliri arasındaki fark alınarak hesaplanan emek dışı gelir değişkenlerinin etkileri incelenmektedir.

Bireylerin işgücüne katılım kararlarını etkileyen etmenlerin incelendiği çalışmada, bağımlı değişken olarak işgücü durumu kullanılmaktadır. 2007'de \%31.78 olan kadın işgücüne katılımı, krizin etkisinin en yoğun yaşandığı 2009'da \%35.92 ile en yüksek seviyesine ulaşmakta ve 2010 yılında küçük bir azalışla \%35.58'e gerilemektedir. Genel olarak bakıldığında işgücüne dahil erkeklerin oranının, kadınlardan 2.5 kat daha fazla olduğu görülmektedir. 2007'de işgücüne dahil erkeklerin oranı \%80.08 iken 2009 'da krizin etkisiyle \%82.32'ye yükselmekte ve 2010 'da $\% 79.82$ ile önemli bir düşüş göstermektedir. İşgücüne katılım oranında meydana gelen artışı daha iyi anlayabilmek için istihdam ve işsizlik oranlarının incelenmesi uygun olacaktır. Kadınlarda krizin etkileri ile birlikte hem istihdam hem de işsizlik oranlarında artış yaşanmaktadır. 2007'de kadınlarda istihdam oranı \%30.40 iken 2009'da \%33.38'e çıkmaktadır. Erkeklerde ise kriz ve sonrası dönemde istihdam oranında azalış görülürken işsizlikte artış gerçekleşmektedir. 2008'de \%76.28 olan erkek istihdam oranı, 2009 'da \%75.16'ya ve 2010 'da da \%74.34'e gerilemektedir. Krizin etkilerinin hissedildiği 2009 'da işsizlik \%7.16 ile en yüksek seviyesine çıkmaktadır. Bu durum kriz döneminde artan erkek işgücüne katılımın işsizlikten kaynaklandığını göstermektedir. Hem işini kaybedenler hem de piyasaya katılanlar ile oluşan işsizlik artışı işgücüne katılımda da artışa neden olmaktadır.

Tablo 1'e göre veri setinde yer alan kadınların ortalama $\% 75$ 'i, erkeklerin ise \%80'i evlidir. Beşeri sermaye işgücüne katılım üzerinde önemli etkiye sahiptir (bknz. Booth ve diğerleri (1999), Taşçı ve Tansel (2005a), Voicu (2005), Cai (2010), Prowse (2012)). Eğitim durumu incelendiğinde erkeklerin eğitim düzeylerinin daha yüksek olduğu görülmektedir. Kadınların yaklaşı \%27'si bir okul bitirmemiştir ve bu oran oldukça yüksektir. Erkeklerde okul bitirmemişlerin oranının sadece \%7 olduğu görüldüğünde eğitimsiz kadınların oranı daha çarpıcı bir hal almaktadır. Hem kadın hem de erkeklerin çoğunluğu ilkokul mezunudur. Üniversite ve üzeri eğitime sahip kadınların oranı \%6, erkeklerin ise \%10'dur. Kadınların ortalama iş tecrübesi 8 yıl iken erkeklerin 18.5 yıldır. Kadınların hem eğitim düzeyi hem de iş tecrübesi erkeklerin oldukça gerisindedir.

Çalışmada 15-64 yaş arası bireyler ile çalışılmaktadır. 2007 yılı itibariyle veri setinde yer alan kadınların yaş ortalaması 36.52 , erkeklerin ise 37.78 'dir. Hanenin toplam yıllık kullanılabilir geliri ile bireyin toplam yıllık kullanılabilir geliri, ilgili yılın Tüketici Fiyat Endeksine bölünerek deflate edilmiştir. Deflate hane geliri ve bireyin geliri arasındaki fark alınarak, emek dışı hane gelirine ulaşılmıştır. 2007 yılında kadınlarda emek dışı hane geliri 11,626 TL, erkeklerde 6,438 TL'dir. 2008'de hem kadın hem de erkeklerin emek dışı hane gelirinde azalma yaşanmakta, 2009'da artarak en yüksek seviyesine çıkmaktadır. Krizin etkilerinin azaldığı 2010'da en düşük seviyesine gerilemektedir.

Literatürde çocuk sahibi olmak özellikle kadın işgücüne katılımında önemli bir belirleyici olarak karşımıza çıkmaktadır (bknz. Hsylop (1999), Haynes ve diğerleri (2006), Tansel ve Kan (2012), Shiu ve Hu (2013)). Özellikle okul öncesi çağda, bakıma muhtaç çocuğa sahip olmak işgücüne katılımın önemli belirleyicilerindendir. 2007'de hanelerin \%35'inde 5 ve daha küçük yaşta en az bir çocuk bulunmaktadır. 2010'da kadınlarda bu oran \%31'e, erkeklerde \%33'e düşmektedir. 


\section{Metodoloji}

Çalışmada bireylerin aile bütçesi kısıtı altında kendi faydalarını en çoklayacak şekilde verdikleri işgücü arzı kararları, işgücüne katılım açısından incelenmektedir. 2007-2010 GYKA panel veri setiyle 15-64 yaş arası kadın ve erkekler için model tahminleri gerçekleştirilmektedir. Ekonometrik modeller iki aşamada tahmin edilmektedir. illk aşamada işgücüne katılım üzerinde etkili olan etmenleri incelemek amacıyla "işgücüne dahil ve işgücüne dahil olmayanlar"dan oluşan iki durumlu bağımlı değişken kullanılmaktadır. İki durumlu panel tercih modelleri ile tahminler gerçekleştirilmekte ve yorumlar yapılmaktadır. İkinci aşamada, işgücüne katılımın istihdam ve işsizlik ayrımı da dikkate alınarak, model tahminleri "istihdam, işsiz ve işgücüne dahil olmayanlar"dan oluşan üç durumlu bağımlı değişken ile yapılmaktadır. Çok durumlu panel tercih modelleri ve yorumlarına yer verilmektedir.

Birinci aşamada bireylerin işgücüne katılım kararlarını etkileyen etmenleri belirlemek amacıyla, işgücü arzını temsilen kullanılan "işgücü durumu" değişkeni; "0: işgücüne dahil olmayan", "1: işgücüne dahil" olmak üzere iki durumlu kesikli bir değişkendir. Bu durumda bağımlı değişken $y_{i t} ; t$ yılında birey i'nin işgücü durumunu temsil etmek üzere, birey işgücüne dahil (istihdamda ya da işsiz) ise 1 değerini almaktadır.

İşgücü teorisine göre bireyin $t$ dönemi için işgücüne katılım kararı genel olarak aşağıdaki gibi ifade edilebilir.

$$
p_{t}=1\left(w_{t}>w_{0 t}^{*}\right)
$$

$p_{t}$ işgücüne katılım durumunu göstermektedir. $w_{t}$ ücret düzeyini, $w_{0 t}^{*}$ ise rezervasyon ücretini temsil etmektedir. 1(.) ise Denklem (1)'deki ifade doğru ise 1'e, yanlış ise 0'a eşit olan gösterge fonksiyonudur. Buna göre $w_{t}$ ücret düzeyi, $w_{0 t}^{*}$ rezervasyon ücretini aştığı noktada birey işgücüne katılmaya karar verir. Panel veri kullanılarak işgücüne katılım kararı modellenirken Denklem (1)'den yararlanılarak elde edilen Denklem (2) kullanılmaktadır (Hyslop, 1999: 1263).

$$
p_{i t}=\operatorname{Pr}\left(y_{i t}=1 \mid \mathbf{x}_{i t}\right)=1\left(\beta^{\prime} \mathbf{x}_{i t}+u_{i t}>0\right) \quad i=1, \ldots, N \quad t=1, \ldots, T
$$

$\mathbf{X}_{i t}$; bağımlı değişkeni etkileyebilecek gözlemlenen beşeri sermaye, demografik özellikler ve aile yapısı gibi açıklayıcı değişkenlerden oluşan bir vektördür. $\beta$, söz konusu açıklayıcı değişkenlere karşılık gelen parametreleri temsil etmektedir. $u_{i t}$, hata terimidir.

Panel veri modelleri arasında seçim yapılırken testler kadar önsel bilgiler de önem arz etmektedir. Çalışmada kullanılan GYKA panel veri seti anakütleden çekilen tesadüfi bireylere ilişkin bilgilerden oluşmaktadır. Bu durum, tesadüfi etkiler modellerinin tercih edilmesi konusunda önsel bir bilgi sağlamaktadır. Çalışmanın amacı bireylerin işgücüne katılım kararları hakkında Türkiye geneli için çıkarsamalar yapmaktır. Belirli birimler yerine örneklemin elde edildiği anakütle hakkında genel çıkarsamalar yapmak amaçlanıyorsa tesadüfi etkiler varsayımı altında model tahmininin gerçekleştirilmesi daha uygundur (Tatoğlu, 2012: 163). 
Sabit etkiler tahmincisi, açıklayıc değişkenlerin $y_{i t}$ üzerindeki etkilerini tahmin ederken, her bir birey için yalnızca $\mathbf{x}_{i t}$ 'lerin ve $y_{i t}$ 'nin zaman içindeki değişimlerinden gelen bilgileri kullanmaktadır (Hill ve diğerleri, 2011: 557). Çalışmada 2,684 kadından 2,509'unun işgücü durumu dört yıl boyunca değişim göstermemektedir. Erkeklerde de 2,319 bireyden 1,900'ünün işgücü durumu dört yıl boyunca aynı kalmaktadır. Rastlantısal parametre problemi ve $y_{i t}$ 'nin zaman içindeki değişiminin düşük olması nedeniyle sabit etkiler ile modeller tahmin edilememektedir.

Açıklamalar doğrultusunda birim etkinin tesadüfi olduğu varsayımı altında hata terimi $u_{i t}$ 'nin Denklem (3)'teki yapıda olduğu varsayılmaktadır.

$$
u_{i t}=\varepsilon_{i t}+\alpha_{i}
$$

$\alpha_{i}$ sıfır ortalamalı ve $\sigma_{\alpha}^{2}$ varyanslı normal dağııımlı tesadüfi değişkendir. $\alpha_{i}$, gözlenemeyen insan sermayesi ve zevkleri içeren birime özgü yapıyı içermektedir. $\varepsilon_{i t}$, birim etki dışında kalan hata terimini temsil etmektedir (Hyslop, 1999: 1263). Bazı kısıtlayıcı varsayımlar altında model En Yüksen Olabilirlik (EYO) yöntemi ile tahmin edilebilir. EYO yönteminde logaritmik olabilirlik fonksiyonunun maksimizasyonu, hesaplama açısından oldukça zor olan $T$ boyutlu integral içermektedir. Alternatif bir yaklaşım, EYO'nun hesaplamasını tek değişkenli integral ile basitleştirmektedir. Hesaplama kolaylığı sağlanması için Butler ve Moffitt (1982) Gauss kareselleştirmesinin kullanılmasını önermiştir (Frees, 2004: 330).

İkinci aşamada "işgücü durumu" değişkeni; "1: işgücüne dahil olmayan", "2: istihdamda" ve "3: işsiz" olmak üzere çok durumlu panel tercih modelleri ile bireylerin işgücüne katılım kararlarını etkileyen etmenler araştırılmaktadır. Bu durumda bağımlı değişken $y_{i t, j}$; birey i'nin $t$ yılında $j$ alternatifini (işgücü durumunu) seçmesi durumunu temsil etmektedir.

Üç işgücü durumunun belirleyicilerini elde etmek amacıyla panel MNL modeli uygulanmaktadır. Modelde her zaman periyodunda bireyin, en yüksek faydayı sağlayacağı işgücü durumunu seçeceği varsayılmaktadır. $j$ durumunda, $t$ zamanındaki birey $i$ için tesadüfi fayda fonksiyonu aşağıdaki gibi kabul edilmektedir.

$$
U_{i t, j}=\beta_{j}^{\prime} x_{i t}+\alpha_{i j}+\varepsilon_{i t, j} \quad i=1, \ldots, N \quad t=1, \ldots, T \quad j=1,2,3
$$

Denklem (4)'teki fayda fonksiyonunda yer alan $\mathbf{x}_{i t}$, gözlemlenen bireysel özellikler vektörü; $\beta_{j}$, açıklayıcı değişkenlerin parametre vektörüdür. Tesadüfi hata bileşeni $\alpha_{i j}$, birime özgü gözlemlenemeyen heterojenliği modellemektedir. $\alpha_{i j}$ birimlere ve alternatiflere göre değişmektedir, fakat zamana göre sabittir. $\alpha_{i j}$ 'nin fayda fonksiyonunda yer alması, MNL modeline iliş̧kisiz Alternatiflerin Bağımsızlığı varsayımının getirdiği kısıtlamayı gevşetmektedir. $\varepsilon_{i t, j}$, bağımsız tip I uç değer dağılımı gösteren hata terimidir (Lechmann ve Wunder, 2016: 4).

Çok durumlu panel tercih modellerinin tahmin edilmesinde simülasyon yöntemlerinden yararlanılmaktadır. Simülasyonda, çekilen simülatör sayısı tahmincinin önemli bir unsurudur. Çok durumlu panel tercih modelleri Benzetimli En Yüksek Olabilirlik (BEYO) yöntemi ile tahmin edilebilir. BEYO yönteminde integral alma Monte Carlo simülasyonu ile yapılabilmektedir (Greene, 2012: 618). 


\section{Ampirik Bulgular ve Değerlendirme}

Çalışmanın ilk aşamasında iki durumlu işgücü durumu değişkeni (0: işgücüne dahil olmayan, 1: işgücüne dahil) ile tesadüfi etkiler panel logit model tahmin edilmektedir. İkinci aşamasında ise üç durumlu işgücü durumu bağımlı değişkeni (1: işgücüne dahil olmayan, 2: istihdamda, 3 : işsiz) kullanılarak panel MNL modeli tahmin edilmekte ve sonuçlar sunulmaktadır.

\section{1. İki Durumlu Panel Tercih Modelleri Tahmin Sonuçları}

Çalışmada kadın ve erkekler için tesadüfi etkiler logit modelleri EYO yöntemi ile tahmin edilmektedir. İntegralleri hesaplamak için Gauss kareselleştirme süreci ve doğru tahminler elde edebilmek amacıyla 30 integral noktası kullanılmaktadır (Rabe-Hesketh ve Skrondal, 2012: 523).

Tablo 2'de kadın ve erkekler için işgücüne katılım kararının tesadüfi etkiler panel logit model tahmin sonuçları yer almaktadır. Gözlemlenemeyen birim etkinin toplam varyans içindeki payı $(\rho)$ kadınlar için \%79.35, erkekler için \%79.20'dir. Bu oranların yüksek olması verilerde birim etkinin önemli bir paya sahip olduğunu göstermektedir. $\rho=0$ 'ın testinde kullanılan Olabilirlik Oran (LR) testi her iki modelde de reddedilmektedir. $\rho$ 'nun 0'dan farklı olması havuzlanmış model ile elde edilen tahmincilerin uygun olmadığını, tesadüfi etkilerin tercih edilmesi gerekliliğini desteklemektedir. Wald testi sonuçlarına göre hem kadın hem de erkek modelleri bütüncül olarak anlamlıdır.

Tablo 2'de yer alan bahis oranları, verilen açıklayıcı değişken için bireyin işgücüne dahil olma olasılığının, olmama olasılığına oranını göstermektedir. Çalışmanın zaman aralığı 2008 finans krizini içermektedir. 2008'in son çeyreğinde patlak veren Türkiye'de etkileri 2009 'da yaşanan krizin işgücüne katılım kararı üzerindeki etkisini araştırmak amacıyla modele yıl kuklaları ilave edilmektedir. 2007 kuklası temel sınıf olmak üzere, 2008 kuklası kriz öncesi dönemi temsil etmektedir. 2009 kuklası ise kriz döneminin özelliklerini yansıtmaktadır. Türkiye'de 2010'da krizin işgücü istatistikleri üzerindeki etkisinin gerilediği düşünüldüğünde, 2010 kuklasının kriz sonrası dönemi temsil etmesi uygundur. Kadınlarda sadece 2009 'da işgücüne katılımda anlamlı bir artış görülmektedir. Bu durum ilave iş̧̧i etkisinin 2008 krizinden sonra etkili olduğunu düşündürmektedir. Erkeklerde 2008, 2009 ve 2010 yıllarında işgücüne katılım artmaktadır. Hatta en yüksek artış kriz dönemi olan 2009 yılındadır ve işgücüne katılımın bahis oranı 1.88 civarındadır.

Evli olmak kadınlar için işgücüne katılım olasılı̆̆ını düşürürken, erkeklerinkini arttırmaktadır. Erkeklerin işgücüne katılımına ilişkin bahis oranının 15.12 çıkması, medeni durumun erkeklerin işgücü durumu üzerinde önemli bir belirleyici olduğunu ortaya koymaktadır.

Beşeri sermaye bireylerin işgücüne katılımında önemli bir faktördür. Kadınlar için elde edilen model incelendiğinde özellikle lise ve üniversite mezunu olmanın işgücüne katılımda anlamlı bir etken olduğu ortaya koyulmaktadır. Üniversite mezunu bir kadının, okul bitirmemiş bir kadına göre işgücüne katılmasının bahis oranı 44 kat fazladır. Üniversite mezunu olmak kadının işgücüne katılımında önemli bir belirleyicidir. Erkekler için lise ve üniversite mezunu olmak işgücüne katılımda pozitif etki yaratmaktadır. Bir diğer beşeri sermaye iş tecrübesi de arttıkça kadın ve erkeğin işgücüne katılımı artmaktadır. 
Tablo 2: Panel Logit Model Tahmin Sonuçları

\begin{tabular}{|c|c|c|c|c|}
\hline \multirow[b]{2}{*}{ Temel Sınıf: İşgücüne Dahil Olmayan } & \multicolumn{2}{|c|}{ KADIN } & \multicolumn{2}{|c|}{ ERKEK } \\
\hline & $\begin{array}{c}\text { Katsayı } \\
\text { (Standart Hata) }\end{array}$ & Bahis Oranı & $\begin{array}{c}\text { Katsayı } \\
\text { (Standart Hata) }\end{array}$ & Bahis Oranı \\
\hline \multicolumn{5}{|l|}{ YII (2007) } \\
\hline 2008 & $\begin{array}{c}0.1455 \\
(0.1132)\end{array}$ & 1.1566 & $\begin{array}{c}0.2938^{* *} \\
(0.1355)\end{array}$ & 1.3415 \\
\hline 2009 & $\begin{array}{l}0.2150 * \\
(0.1161)\end{array}$ & 1.2399 & $\begin{array}{c}0.6298 * * * \\
(0.1411)\end{array}$ & 1.8772 \\
\hline 2010 & $\begin{array}{c}0.1831 \\
(0.1193)\end{array}$ & 1.2009 & $\begin{array}{l}0.3284^{* *} \\
(0.1414)\end{array}$ & 1.3888 \\
\hline \multicolumn{5}{|l|}{ Medeni Durum (Bekar) } \\
\hline Evli & $\begin{array}{c}-0.8289 * * * \\
(0.2461)\end{array}$ & 0.4365 & $\begin{array}{c}2.7160 * * * \\
(0.3870)\end{array}$ & 15.1204 \\
\hline \multicolumn{5}{|l|}{ Eğitim Durumu (Bir okul bitirmemiş) } \\
\hline illkokul mezunu & $\begin{array}{c}0.1007 \\
(0.2375)\end{array}$ & 1.1060 & $\begin{array}{c}0.2600 \\
(0.3699)\end{array}$ & 1.2969 \\
\hline Ortaokul mezunu & $\begin{array}{c}0.1927 \\
(0.3249)\end{array}$ & 1.2126 & $\begin{array}{l}-0.0073 \\
(0.4005)\end{array}$ & 0.9928 \\
\hline Lise mezunu & $\begin{array}{c}0.6073^{* *} \\
(0.3014)\end{array}$ & 1.8355 & $\begin{array}{l}0.6590 * \\
(0.3986)\end{array}$ & 1.9328 \\
\hline Üniversite ve üzeri mezunu & $\begin{array}{c}3.7929 * * * \\
(0.4128)\end{array}$ & 44.3863 & $\begin{array}{c}1.3399 * * * \\
(0.4817)\end{array}$ & 3.8186 \\
\hline İş Tecrübesi & $\begin{array}{c}0.3124 * * * \\
(0.0113)\end{array}$ & 1.3667 & $\begin{array}{c}0.1219 * * * \\
(0.0125)\end{array}$ & 1.1296 \\
\hline Bireyin Yaşı & $\begin{array}{c}0.4700 * * * \\
(0.0530)\end{array}$ & 1.6001 & $\begin{array}{c}0.8389 * * * \\
(0.0643)\end{array}$ & 2.3138 \\
\hline Bireyin Yaşının Karesi & $\begin{array}{c}-0.0086 * * * \\
(0.0007)\end{array}$ & 0.9914 & $\begin{array}{c}-0.0135^{* * *} \\
(0.0008)\end{array}$ & 0.9866 \\
\hline (Hanenin Geliri - Bireyin Geliri)/1000 & $\begin{array}{c}-0.0174 * * \\
(0.0076)\end{array}$ & 0.9828 & $\begin{array}{c}-0.0329 * * * \\
(0.0097)\end{array}$ & 0.9676 \\
\hline \multicolumn{5}{|c|}{ Hanede 5 ve Daha Küçük Yaşta Çocuk Olması (Yok) } \\
\hline Var & $\begin{array}{c}-0.8466 * * * \\
(0.1617)\end{array}$ & 0.4289 & $\begin{array}{l}0.3643^{*} \\
(0.2083)\end{array}$ & 1.4395 \\
\hline Sabit & $\begin{array}{c}-8.2433^{* * *} \\
(0.9133) \\
\end{array}$ & 0.0003 & $\begin{array}{c}-10.6852^{* * *} \\
(1.0968)\end{array}$ & 0.00002 \\
\hline $\ln \left(\sigma_{\alpha}^{2}\right)$ & \multicolumn{2}{|c|}{$\begin{array}{c}2.5370 \\
(0.0767)\end{array}$} & \multicolumn{2}{|c|}{$\begin{array}{c}2.5277 \\
(0.0965)\end{array}$} \\
\hline$\sigma_{\alpha}$ & \multicolumn{2}{|c|}{$\begin{array}{c}3.5556 \\
(0.1364)\end{array}$} & \multicolumn{2}{|c|}{$\begin{array}{c}3.5390 \\
(0.1708)\end{array}$} \\
\hline$\rho$ & \multicolumn{2}{|c|}{$\begin{array}{c}0.7935 \\
(0.0126)\end{array}$} & \multicolumn{2}{|c|}{$\begin{array}{c}0.7920 \\
(0.0159)\end{array}$} \\
\hline Gözlem Sayısı & \multicolumn{2}{|c|}{10736} & \multicolumn{2}{|c|}{9276} \\
\hline Birim Sayısı & \multicolumn{2}{|c|}{2684} & \multicolumn{2}{|c|}{2319} \\
\hline Yıl Sayısı & \multicolumn{2}{|c|}{4} & \multicolumn{2}{|c|}{4} \\
\hline Log olabilirlik & \multicolumn{2}{|c|}{-3507.4656} & \multicolumn{2}{|c|}{-2418.8576} \\
\hline Wald chi2 (13) & \multicolumn{2}{|c|}{$848.25^{* * *}$} & \multicolumn{2}{|c|}{$543.02 * * *$} \\
\hline LR chi2(01) & \multicolumn{2}{|c|}{$2245.13^{* * *}$} & \multicolumn{2}{|c|}{$1514.43^{* * *}$} \\
\hline
\end{tabular}


Not: *** \%1 düzeyinde, $* * \% 5$ düzeyinde, $* \% 10$ düzeyinde anlamlı olduğunu göstermektedir. $\ln \left(\sigma_{\alpha}^{2}\right)$ birim etkinin varyansının logaritmasını; $\sigma_{\alpha}$ birim etkinin standart hatasını ve $\rho$ da birim etkiye ait varyans öğesinin toplam varyans içindeki payını göstermektedir.

Yaş ile işgücüne katılım olasılığı arasında eğrisel bir ilişki bulunmaktadır. Kadın ve erkeklerde yaş ilerledikçe işgücüne katılım önce artarak artmakta daha sonra ise azalmaktadır. Hanenin toplam gelirinden bireyin geliri çıkarılarak elde edilen emek dışı hane geliri arttıkça bireyin işgücüne katılma olasılığı düşmektedir. Bireyler gelir etkisi ile işgücüne katılmak yerine işgücü dışında kalmayı tercih etmektedir.

Literatürde bakıma muhtaç okul öncesi yaşta çocuk sahibi olmak kadınları işgücü dışına iten önemli etmenlerden biri olarak karşımıza çıkmaktadır. Model sonuçlarına göre yaşadığı hanede beş yaşından küçük çocuk olan kadınların işgücüne katılım olasılıkları azalırken, erkeklerin olasılığı artmaktadır.

\section{2. Çok Durumlu Panel Tercih Modelleri Tahmin Sonuçları}

İki durumlu panel tercih model sonuçları bireylerin işgücüne katılım kararları üzerinde etkili olan etmenler hakkında bilgi vermektedir. Ancak işgücü istihdam ve işsizlerden oluşmaktadır. Çok durumlu panel tercih modellerinde bireylerin işgücüne katılım kararlarını etkileyen etmenleri belirlemek amacıyla kullanılan "işgücü durumu" değişkeni; "1: işgücüne dahil olmayan", "2: istihdamda" ve "3: işsiz" olmak üzere üç durumlu kesikli bir değişkendir. Kadın ve erkekler için tesadüfi etkiler MNL modelleri BEYO yöntemi ile tahmin edilmekte ve integral alma yöntemi olarak MCMC simülasyonu kullanılmaktadır. Her fayda fonksiyonu için ayrı ve bağımsız etkiler varsayımı altında Tablo 3 'teki modellere ulaşıımıştır.

Tablo 3 'te işgücüne dahil olmayanların temel sınıf olduğu tesadüfi etkiler panel MNL model sonuçları bulunmaktadır. İstihdam ve işsiz alternatifleri için toplam varyans içindeki birim etkiye ait varyansın payını veren $\rho$ 'lar tablodadır. Buna göre kadın modelinde istihdam alternatifinin $\rho$ 'su \%94, işsiz alternatifinin \%76'dır. Erkek modelinde ise söz konusu oranlar sırası ile \%94 ve \%82 olarak elde edilmektedir. Söz konusu oranların yüksek olması birim etkiye ait varyans öğesinin toplam varyans içindeki payınının yüksek olduğunu göstermektedir. Bu durum gözlenemeyen birim etkinin, modele ilave edilmesi gerekliliğini vurgulamaktadır.

íki durumlu panel tercih modelleri ile kriz döneminde işgücüne katılımda anlamlı bir artış olduğu ortaya koyulmuştur (bknz. Tablo 2). Ancak şimdi işgücüne katılımın istihdama mı yoksa işsizliğe mi olduğu sorusu karşımıza çıkmaktadır. Tablo 3'teki MNL modeline göre kadınların 2007'ye göre istihdamda olmalarında anlamlı bir değişim yoktur. Fakat işsiz olma olasılıkları üzerinde 2009 ve 2010'da anlamlı ve pozitif bir etki olduğu görülmektedir. Kriz ve sonrasında işgücüne dahil olmayan kadınlar, işgücüne katılmaktadır, ancak istihdama geçişlerinde anlamlı bir etki yoktur. Ne yazık ki kadınlar ekonomik kriz nedeniyle iş bulamamış ve işsiz konumunda iş aramıştır. Erkeklerde 2007'ye göre her dönemde hem istihdamda hem de işsizlikte anlamlı bir artış görülmektedir. 2009 ve 2010 'da işsiz olma olasılıkları daha yüksektir. Tablo 3'te görüldüğü üzere erkeklerin 2009 'da istihdamda olma ihtimali 1.6 kat, işsiz olma ihtimali 2.3 kat fazladır.

Evli kadınların işgücü dışına göre istihdamda ya da işsiz olma olasılıkları daha düşüktür. Ayrıca işgücüne katılmaya karar veren evli bir kadının işsiz olma olasılığı görece daha yüksektir. 
Kadınların aksine evli erkeklerin istihdamda ve işsiz olma olasılıkları, bekar erkeklere göre daha yüksektir. Evli bir erkeğin işsiz olma olasılığı 3.6 kat daha fazla iken, istihdamda olma olasılığı 25 kat yüksektir.

Tablo 3: Panel MNL Model Tahmin Sonuçları

\begin{tabular}{|c|c|c|c|c|c|c|c|c|}
\hline & \multicolumn{4}{|c|}{ KADIN } & \multicolumn{4}{|c|}{ ERKEK } \\
\hline $\begin{array}{l}\text { Temel Sı- } \\
\text { nıf: İşgü- } \\
\text { cüne Dahil } \\
\text { Olmayan }\end{array}$ & \multicolumn{2}{|c|}{ İstihdamda } & \multicolumn{2}{|c|}{ İşsiz } & \multicolumn{2}{|c|}{ İstihdamda } & \multicolumn{2}{|c|}{ İşsiz } \\
\hline $\begin{array}{l}\text { Değişken- } \\
\text { ler }\end{array}$ & $\begin{array}{c}\text { Katsayı } \\
\text { (Standart } \\
\text { Hata) }\end{array}$ & $\begin{array}{l}\text { Bahis } \\
\text { Oranı }\end{array}$ & $\begin{array}{c}\text { Katsayı } \\
\text { (Standart } \\
\text { Hata) }\end{array}$ & $\begin{array}{l}\text { Bahis } \\
\text { Oranı }\end{array}$ & $\begin{array}{c}\text { Katsayı } \\
\text { (Standart } \\
\text { Hata) }\end{array}$ & $\begin{array}{l}\text { Bahis } \\
\text { Oranı }\end{array}$ & $\begin{array}{c}\text { Katsayı (Stan- } \\
\text { dart Hata) }\end{array}$ & $\begin{array}{l}\text { Bahis } \\
\text { Oranı }\end{array}$ \\
\hline \multicolumn{9}{|l|}{$Y_{I I}(2007)$} \\
\hline 2008 & $\begin{array}{c}0.1092 \\
(0.1376)\end{array}$ & 1.1154 & $\begin{array}{c}0.3675 \\
(0.2523)\end{array}$ & 1.4441 & $\begin{array}{l}0.3042^{*} \\
(0.1569)\end{array}$ & 1.3555 & $\begin{array}{c}0.2229 \\
(0.1903)\end{array}$ & 1.2497 \\
\hline 2009 & $\begin{array}{c}0.1162 \\
(0.1186)\end{array}$ & 1.1233 & $\begin{array}{c}0.6923 * * * \\
(0.2372)\end{array}$ & 1.9984 & $\begin{array}{c}0.4896 * * * \\
(0.1511)\end{array}$ & 1.6316 & $\begin{array}{c}0.8333^{* * *} \\
(0.1818)\end{array}$ & 2.3010 \\
\hline 2010 & $\begin{array}{c}0.0814 \\
(0.1119)\end{array}$ & 1.0848 & $\begin{array}{c}0.6923 * * * \\
(0.2243)\end{array}$ & 1.9983 & $\begin{array}{c}0.2608 * * \\
(0.1283) \\
\end{array}$ & 1.2979 & $\begin{array}{c}0.3500 * * \\
(0.1681) \\
\end{array}$ & 1.4191 \\
\hline \multicolumn{9}{|c|}{ Medeni Durum (Bekar) } \\
\hline Evli & $\begin{array}{c}-0.5938 * * * \\
(0.1205)\end{array}$ & 0.5522 & $\begin{array}{c}-1.4626^{* * *} \\
(0.1754)\end{array}$ & 0.2316 & $\begin{array}{c}3.2319 * * * \\
(0.2160)\end{array}$ & 25.3277 & $\begin{array}{c}1.2741^{* * *} \\
(0.2113)\end{array}$ & 3.5754 \\
\hline \multicolumn{9}{|c|}{ Eğitim Durumu (Bir okul bitirmemiş) } \\
\hline $\begin{array}{l}\text { Illkokul } \\
\text { mezunu }\end{array}$ & $\begin{array}{c}0.0044 \\
(0.1143)\end{array}$ & 1.0044 & $\begin{array}{c}0.8282^{* * *} \\
(0.2603)\end{array}$ & 2.2892 & $\begin{array}{c}0.7404^{* * *} \\
(0.1697)\end{array}$ & 2.0967 & $\begin{array}{c}0.0672 \\
(0.1735)\end{array}$ & 1.0695 \\
\hline $\begin{array}{l}\text { Ortaokul } \\
\text { mezunu }\end{array}$ & $\begin{array}{l}-0.0258 \\
(0.1617)\end{array}$ & 0.9745 & $\begin{array}{c}1.1980 * * * \\
(0.2998)\end{array}$ & 3.3135 & $\begin{array}{c}0.6249 * * * \\
(0.1938)\end{array}$ & 1.8681 & $\begin{array}{l}-0.0513 \\
(0.1923)\end{array}$ & 0.9500 \\
\hline $\begin{array}{l}\text { Lise me- } \\
\text { zunu }\end{array}$ & $\begin{array}{c}0.3647^{* *} \\
(0.1494)\end{array}$ & 1.4401 & $\begin{array}{c}1.7022^{* * *} \\
(0.2966)\end{array}$ & 5.4858 & $\begin{array}{c}1.4393^{* * *} \\
(0.1948)\end{array}$ & 4.2178 & $\begin{array}{c}0.1551 \\
(0.1977)\end{array}$ & 1.1678 \\
\hline $\begin{array}{l}\text { Üniversite } \\
\text { ve üzeri } \\
\text { mezunu }\end{array}$ & $\begin{array}{c}3.8996 * * * \\
(0.2028)\end{array}$ & 49.3847 & $\begin{array}{c}3.6846 * * * \\
(0.3283)\end{array}$ & 39.8300 & $\begin{array}{c}2.4094^{* * *} \\
(0.2410)\end{array}$ & 11.1271 & $\begin{array}{c}0.0033 \\
(0.2802)\end{array}$ & 1.0033 \\
\hline İş Tecrübesi & $\begin{array}{c}0.3326 * * * \\
(0.0066)\end{array}$ & 1.3946 & $\begin{array}{c}0.1288 * * * \\
(0.0136)\end{array}$ & 1.1375 & $\begin{array}{c}0.1301 * * * \\
(0.0072)\end{array}$ & 1.1389 & $\begin{array}{c}0.0576 * * * \\
(0.0097)\end{array}$ & 1.0593 \\
\hline Bireyin Yaşı & $\begin{array}{c}0.4790 * * * \\
(0.0255)\end{array}$ & 1.6145 & $\begin{array}{c}0.4160 * * * \\
(0.0519)\end{array}$ & 1.5158 & $\begin{array}{c}0.9027^{* * *} \\
(0.0354)\end{array}$ & 2.4663 & $\begin{array}{c}0.69772 * * * \\
(0.0365)\end{array}$ & 2.0092 \\
\hline $\begin{array}{l}\text { Bireyin Yaşı- } \\
\text { nın Karesi } \\
\text { (Hanenin }\end{array}$ & $\begin{array}{c}-0.0089 * * * \\
(0.0003)\end{array}$ & 0.9912 & $\begin{array}{c}-0.0070 * * * \\
(0.0008)\end{array}$ & 0.9930 & $\begin{array}{c}-0.0144 * * * \\
(0.0005)\end{array}$ & 0.9857 & $\begin{array}{c}-0.0108 * * * \\
(0.0005)\end{array}$ & 0.9893 \\
\hline $\begin{array}{l}\text { Geliri - Bire- } \\
\text { yin Ge- } \\
\text { (iri)/1000 }\end{array}$ & $\begin{array}{c}-0.0125 * * \\
(0.0050)\end{array}$ & 0.9876 & $\begin{array}{c}-0.0541 * * * \\
(0.0126)\end{array}$ & 0.9473 & $\begin{array}{c}-0.0406 * * * \\
(0.0060)\end{array}$ & 0.9602 & $\begin{array}{c}-0.0222 * * * \\
(0.0061)\end{array}$ & 0.9780 \\
\hline \multicolumn{9}{|c|}{ Hanede 5 ve daha Küçük Yaşta Çocuk Olması (Yok) } \\
\hline Var & $\begin{array}{c}-0.9153^{* * *} \\
(0.0999)\end{array}$ & 0.4004 & $\begin{array}{c}-0.8456 * * * \\
(0.1901)\end{array}$ & 0.4293 & $\begin{array}{c}0.3987 * * * \\
(0.1227)\end{array}$ & 1.4899 & $\begin{array}{c}0.2885^{* *} \\
(0.1403)\end{array}$ & 1.3344 \\
\hline Sabit & $\begin{array}{c}-8.7709 * * * \\
(0.4526)\end{array}$ & 0.0002 & $\begin{array}{c}-8.9894 * * * \\
(0.8430)\end{array}$ & 0.0001 & $\begin{array}{c}12.5430 * * * \\
(0.5900)\end{array}$ & $\begin{array}{c}0.00000 \\
4 \\
\end{array}$ & $\begin{array}{c}-10.1188^{* * *} \\
(0.6016)\end{array}$ & 0.00004 \\
\hline$\sigma_{i, j}$ & $\begin{array}{r}3.908 \\
10.08\end{array}$ & & $\begin{array}{r}1.7645 \\
(0.12\end{array}$ & & $\begin{array}{r}4.096 \\
(0.10\end{array}$ & & $\begin{array}{r}2.1528 \\
(0.108\end{array}$ & \\
\hline$\rho$ & 0.93 & & 0.75 & & 0.94 & & 0.822 & \\
\hline $\begin{array}{l}\text { Gözlem } \\
\text { Sayısı }\end{array}$ & \multicolumn{4}{|c|}{10736} & \multicolumn{4}{|c|}{9276} \\
\hline $\begin{array}{l}\text { Birim } \\
\text { Sayısı }\end{array}$ & \multicolumn{4}{|c|}{2684} & \multicolumn{4}{|c|}{2319} \\
\hline $\begin{array}{l}\text { Yıl } \\
\text { Sayısı }\end{array}$ & \multicolumn{4}{|c|}{4} & \multicolumn{4}{|c|}{4} \\
\hline $\begin{array}{l}\text { Log } \\
\text { olabilirlik }\end{array}$ & \multicolumn{4}{|c|}{-4120.3113} & \multicolumn{4}{|c|}{-4005.2086} \\
\hline $\mathrm{AIC}$ & \multicolumn{4}{|c|}{8300.6} & \multicolumn{4}{|c|}{8070.4} \\
\hline
\end{tabular}


Not: $* * * \% 1$ düzeyinde, $* * \% 5$ düzeyinde, $* \% 10$ düzeyinde anlamlı olduğunu göstermektedir. $\sigma_{i, j}, j$ alternatifi için gözlenemeyen tesadüfi birim etkilerin standart hatasıdır. $\rho, j$ alternatifi için birim etkiye ait varyans öğesinin toplam varyans içindeki payını göstermektedir.

Eğitim ve iş tecrübesi beşeri sermayeyi oluşturan iki önemli unsurdur. Eğitim durumuna göre elde edilen sonuçlar kadın ve erkekler için farklıdır. Kadınlar için eğitim düzeyi arttıkça işsiz olma olasılığı da artmaktadır. illkokul mezunu bir kadının, işsiz olma intimali 2 kat, üniversite mezununun 40 kat kadar fazladır. İstihdamda olma durumları incelendiğinde lise ve üniversite mezunları için anlamlı sonuçlar elde edilmektedir. Lise mezunu bir kadının, istihdamda olma olasılığı 1.44 kat, üniversite mezununun istihdamda olma olasılığı 49 kat fazladır. Erkeklerin eğitim düzeyinin işsiz olmasında anlamlı bir etkisi yoktur. Eğitim düzeyi artan erkeğin istihdamda olma olasılığı da artmaktadır; üniversite mezunu bir erkeğin istihdamda olma ihtimali 11 kat fazladır. İ̧ tecrübesindeki artış hem kadın hem de erkeklerin istihdamda ya da işsiz olma olasılıklarını arttırırken, istihdamda olma ihtimalleri göreli olarak daha yüksektir.

Bireyin yaşı ile istihdamda ya da işsiz olma durumu arasında eğrisel bir ilişki olduğu görülmektedir. Bireylerin istihdamda ya da işsiz olma ihtimalleri yaş ilerledikçe önce artış gösterirken, daha sonra emeklilik ve yaşlılık etkisiyle azalmaktadır.

Emek dışı hane gelirinde artış olması bireylerin işgücüne katılımını olumsuz etkilemektedir. Hanedeki gelirin artması kadın ve erkeklerin istihdamda ya da işsiz olma olasılıklarını düşürmektedir. Kadın ve erkeklerin katsayıları karşılaştırıldığında gelir etkisinin cinsiyete göre farklılaşmadığı görülmektedir.

Hanede beş yaşından küçük çocuk olması kadınların istihdama ya da işsizliğe katılımı üzerinde negatif etki yaparken, erkeklerde pozitif etki yaratmaktadır. Küçük çocuk sahibi bireylerin istihdamda ve işsiz olma olasılıkları karşılaştırıldığında katsayıların birbirine oldukça yakın olduğu görülmektedir.

\section{Sonuç}

Elde edilen bulgulara göre krizin etkilerinin yaşandığı 2009'da kadınların işgücüne katılımda artış yaşanmış ve bu artış işsizliğin artması ile ortaya çıkmıştır. 2009'da ilave iş̧̧i etkisi ile işgücüne katılan kadınların istihdama katılımlarında anlamlı bir etki bulunmamaktadır. Erkeklerde kriz ve sonrası dönemde işgücüne katılım artış gösterirken, hem istihdam hem de işsizliğe geçişte anlamlı bir etki vardır. Ancak işsizliğe geçme olasılığı görece daha yüksektir.

Çalışmada hanenin toplam gelirinden bireyin geliri çıkarılarak elde edilen emek dışı hane gelirinin etkisi araştırımaktadır. Emek dışı hane gelirinin artması kadın ve erkeklerin işgücüne katılma olasılığını düşürmektedir, gelir etkisi baskın gelmektedir. Modellerde yaş ile işgücüne katılım olasılığı arasında eğrisel bir ilişki olduğu ortaya koyulmaktadır. Kadın ve erkeklerin yaşı ilerledikçe işgücüne katılımı deneyimin de artmasıyla önce artarak artmakta, daha sonra ise emeklilik ve yaşlılık gibi faktörlerin etkisiyle azalmaktadır.

Eğitim kadının, işgücüne katılımında önemli bir belirleyici olarak karşımıza çıkmaktadır. Özellikle kadınların işgücüne katılımda üniversite mezunu olmak önemli bir etkendir. Üniversite mezunu bir kadının, işgücüne katılma olasılığı 44 kat fazla iken istihdamda olma olasılığı 49 kat fazladır. Kadınların üniversite eğitimi almasının desteklenmesi durumunda işgücüne katılımın artacağı ortadadır. Türkiye'de eğitim düzeyi lise ve altında olan kadınların işgücüne katılımı dü- 
şüktür. Zorunlu eğitimini tamamlayarak lise mezunu olan kadınlar için uygun istihdam ve çaış̧ma koşullarının oluşturulması, Türkiye'de kadın işgücüne katılımının arttırılması açısından önemlidir.

Literatürde medeni durumun kadınların işgücüne katılımında önemli bir belirleyici olduğu vurgulanmaktadır. Elde edilen bulgular medeni durumun işgücüne katılımda erkekler için de önemli bir etken olduğunu ortaya koymaktadır. Evlilik kadınların işgücüne katılma olasılı̆̆ını azaltırken, erkeklerinkini arttırmaktadır. Evli erkeklerin istihdamda olma olasılığı, 25 kat yüksektir. Elde edilen tahmin sonuçlarına göre yaşadığı hanede beş yaşından küçük çocuk olan kadınların işgücüne katılım olasılıkları azalırken, erkeklerin olasılı̆̆ı artmaktadır. Okul öncesi çağda çocuk sahibi olmak kadınların rezervasyon ücretlerini arttırmakta ve işgücüne katılmalarını zorlaştırmaktadır. Okul öncesi çağda çocukların bakım hizmetlerinin kurumsallaştırılması ve masrafların düşürülmesi kadınların işgücüne katılımda olumlu etki yapacaktır.

Çalışmanın zaman boyutu kısa olduğu için ve 2008 krizinin etkilerinin belirlenebilmesi amacıyla statik panel tercih modelleri ile çalışılmıştır. Sonraki çalışmalarda dinamik panel tercih modelleri ile bir önceki dönemin işgücü arzı üzerindeki etkisinin araştırılması faydalı olacaktır. 


\section{Kaynaklar}

Acar, Elif Öznur; Tansel, Aysıt (2016), "Defining and Measuring Informality: The Case of Turkish Labor Market", Sosyoekonomi, Vol. 24(28): 147-174.

Alcan, Deniz; Can, Raif; Pektaş, Betül (2015), "Türkiye İşgücü Piyasasında Hareketlilik: Mikro Veriye Dayalı Analiz”, Kalkınma Bakanlığı Ekonomi Çalışma Tebliğleri Serisi, No: 2015/1.

Bahçe Kaya, Seçil; Memiş, Emel (2014), "The Uncounted Who Wish to Work-Distinct to the Unemployed or Similar?", Sosyoekonomi, Vol. 21(1): 305-333.

Becker, Gary S. (1965), “A Theory of the Allocation of Time”, The Economic Journal, Vol. 75, No. 299: 493-517.

Booth, Alison L.; Jenkins, Stephen P.; Serrano, Carlos Garcia (1999), “New Men and New Women? A Comparison of Paid Work Propensities from a Panel Data Perspective", Oxford Bulletin of Economics and Statistics, 61(2): 167-197.

Butler, J. S.; Moffitt, Robert (1982), "A Computationally Quadrature for the One-Factor Multinomial Probit Model", Econometrica, Vol. 50, No. 3: 761-764.

Cai, Lixin (2010), "Work Choices of Married Women: Drivers of Change”, Visiting Researcher Paper, Productivity Commission, Canberra.

Croda, Enrica; Kyriazidou, Ekaterini; Polycarpou, loannis (2011), "Intertemporal Labor Force Participation of Married Women in Germany: A Panel Data Analysis", Working Paper Department of Economics of the Ca' Foscari University of Venice, No:17.

Frees, Edward W. (2004), Longitudinal and Panel Data: Analysis and Applications in the Social Sciences, New York: Cambridge University Press.

Greene, William H. (2012) LIMDEP Version 10 Econometric Reference Guide, New York: Econometric Software, Inc.

Haan, Peter (2010), "A Multi-State Model of State Dependence in Labor Supply: Intertemporal Labor Supply Effects of a Shift from Joint to Individual Taxation", Labor Economics, 17: 323-335.

Haynes, Michele; Western, Mark; Yu, Laurel; Spallek, Melanie (2006), “Methods for Categorical Longitudinal Survey Data: Understanding Employment Status of Australian Women", Methods for Longitudinal Surveys (MOLS2006) Conference, University of Essex, Colchester, United Kingdom, July 12-14, 2006. (pp. 1-25).

Heckman, James J.; Willis, Robert J. (1977), “A Beta-Logistic Model for the Analysis of Sequential Labor Force Participation by Married Women", The Journal of Political Economy, Vol. 85, Issue. 1: 27-58.

Hill, R. Carter; Griffiths, William E.; Lim, Guay C. (2011), Principles of Econometrics, Fourth Edition, United States of America: John Wiley \& Sons.

Hyder, Asma; Behrman, Jere R. (2014), “Female Economic Activity in Rural Malawi”, J Dev Leadersh, 3(1): 1-10.

Hyslop, Dean R. (1999), "State Dependence, Serial Correlation and Heterogeneity in Intertemporal Labor Force Participation of Married Women", Econometrica, Vol. 67, No. 6: 1255-1294.

İkizler, Hüseyin; Tunalı, İnsan (2012), “Agricultural Transformation and Labor Mobility During the ARIP Period in Turkey: Evidence From Micro-Data, 2000-2002", Economic Research Forum Working Paper Series, No: 706.

Keane, Michael P.; Sauer, Robert M. (2010), “A Computationally Practical Simulation Estimation Algorithm for Dynamic Panel Data Models with Unobserved Endogenous State Variables", International Economic Review, Vol. 51, No. 4: 925-958.

Lechmann, Daniel S. J.; Wunder, Christoph (2016), “The Dynamics of Solo Self-Employment: Persistence and Transition to Employership", Labor and Socio-Economic Research Center Discussion Papers, No: 96.

Nakamura, Alice; Nakamura, Masao (1985), "Dynamic Models of the Labor Force Behavior of Married Women Which can be Estimated Using Limited Amounts of Past Information", Journal of Econometrics, 27: 273-298.

Özer, Mustafa; Biçerli, Kemal (2003), "Türkiye'de Kadın İşgücünün Panel Veri Analizi”, Anadolu Üniversitesi Sosyal Bilimler Dergisi, 3(1): 55-85.

Prowse, Victoria (2012), "Modeling Employment Dynamics with State Dependence and Unobserved Heterogeneity", Journal of Business\&Economic Statistics, Vol. 30, No. 3: 411-431.

Rabe-Hesketh, Sophia; Skrondal, Anders (2012), Multilevel and Logitudinal Modeling Using Stata Volume II: Categorical Responses, Counts and Suvival, Third Edition, Texas: Stata Press.

Selim, Sibel; Kırgel, H. Duygu; Çelik, Orkun; Yazıcıoğlu, Hakan (2014), “Türkiye'de İşsizliğin Sosyo-Ekonomik Belirleyicileri: Panel Veri Analizi”, Uluslararası Yönetim Iktisat ve Işletme Dergisi, Cilt. 10, Sayı. 22: 1-25. 


\section{Eskişehir Osmangazi Üniversitesi IïB Dergisi}

Shiu, Ji-Liang; Hu, Yingyao (2013), “Identification and Estimation of Nonlinear Dynamic Panel Data Models with Unobserved Covariates”, Journal of Econometrics, 175(2013): 116-131.

Tansel, Aysıt; Kan, Elif Öznur (2012), “Labor Mobility Across The Formal/Informal Divide in Turkey: Evidence from Individual Level Data", ERC Working Papers in Economics, No:12/01.

Taşçı, H. Mehmet; Tansel, Aysıt (2005a), “Unemployment and Transitions in the Turkish Labor Market: Evidence from Individual Level Data", IZA Discussion Paper, No: 1663.

Taşçı, H. Mehmet; Tansel, Aysıt (2005b), "Youth Unemployment Duration in Turkey", METU Studies in Development, 32: 517-545.

TÜSIAD; KAGIDER (2008), Türkiye'de Toplumsal Cinsiyet Eşitsizliği: Sorunlar, Öncelikler ve Çözüm Önerileri, İstanbul: Graphis Matbaa.

Voicu, Aleaxandru (2005), "Employment Dynamics in the Romanian Labor Market. A Markov Chain Monte Carlo Approach", Journal of Comparative Economics, 33(2005): 604-639.

Yerdelen Tatoğlu, Ferda (2012), Panel Veri Ekonometrisi: Stata Uygulamalı, İstanbul: Beta. 